International Journal of Instruction

e-ISSN: 1308-1470 • www.e-iji.net
July $2019 \bullet$ Vol.12, No.3

p-ISSN: 1694-609X

pp. $325-340$

Received: 15/11/2018

Revision: 30/03/2019

Accepted: 08/04/2019

OnlineFirst:05/05/2019

\title{
Effect of Process Writing Approach Combined with Video-Based Mobile Learning on Indonesian EFL Learners' Writing Skill across Creativity Levels
}

\section{Imelda}

Graduate Program in ELT, Universitas Negeri Malang \& SMKN 2 (Vocational High School) Batu, East Java, Indonesia, ime3lda@gmail.com

\section{Bambang Yudi Cahyono}

Prof., English Department, Universitas Negeri Malang, East Java, Indonesia, yudic2000@yahoo.com

\section{Utari Praba Astuti}

Head of the Culture and Language Center, Lecturer of English Department, Universitas Negeri Malang, East Java, Indonesia, utari_pastuti@yahoo.com

This study aims at investigating the effect of process writing approach combined with video-based mobile learning on the writing skill of Indonesian learners of English as a foreign language (EFL) across their creativity levels. A quasiexperimental study was employed by involving 61 learners of Vocational High School learners in Indonesia. They were assigned into two groups: experimental and control. The treatment was conducted at 5 sessions, including the pre-test and post-test. The scores of pre-test and post-test in writing were used as a base of quantitative data analysis whereas the learners' responses to creativity questionnaire were used to categorize their creativity level. The result revealed that the process writing approach combined with video-based mobile learning was effective to enhance the learners' writing skill. Additionally, it was implied that to apply the combination of process writing approach and video-based mobile learning, teachers should not worry about the difference levels of the learners' creativity.

Keywords: EFL learners, high-creativity learners, low-creativity learners, mobile learning, process writing approach, video assignment, writing skill

\section{INTRODUCTION}

In today's society that demands the use of English as a medium of written communication, writing skill is considerably salient to be acquired. Writing is

Citation: Imelda, Cahyono, B. Y., \& Astuti, U. P. (2019). Effect of Process Writing Approach Combined with Video-Based Mobile Learning on Indonesian EFL Learners' Writing Skill Across Creativity Levels. International Journal of Instruction, 12(3), 325-340. https://doi.org/10.29333/iji.2019.12320a 
beneficial to convey information throughout the world (Cahyono, 2009), express ideas, and promote thinking ability (Klimova, 2013). Nevertheless, writing in a foreign language is seen as the most challenging skill to be taught among other three language skills (Timothy Kolade, 2012; Richard \& Renandya, 2013). The dilemma experienced by EFL learners in mastering writing were due to the lack of knowledge in grammatical features and vocabulary items (Hyland, 2003) as well as the low motivation of learners and strain in writing influenced by the ineffective teaching strategy and outdated teaching style (Fareed et al., 2016). In Indonesia, the low achievement in writing was not only caused by those reasons, but also the minimum portion treatment in practicing writing (Cahyono \& Widiati, 2006).

In reference to the poor performance of EFL learners in writing skill, a new teaching strategy should be created to attain the learners' interest and confidence in composition writing. It is believed that the strategy of process writing approach is able to enhance the learners' writing skill. Some studies reported that the process writing approach was found beneficial in helping learners to create ideas confidently and spawn the learners' original notion in essay writing (Arslan \& Kizil, 2010; Timothy Kolade, 2012; Arici \& Kaldirin, 2015; Faraj, 2015; Papilaya, 2018).

In addition, with the development of Information and Communication Technology (ICT) and the inclusion of the Internet in today's education, EFL teachers attempt to use teaching and learning materials which are more relevant to the lifestyles and real-life needs of the $\mathrm{Z}$ generation learners. These learners who were born in the years between 1995 and 2014 were characterized by intense use of technologies in daily life. Nowadays, EFL learners are likely to use their mobile gadgets to work on their school assignments. They also prefer using search engines to visiting libraries in order to find books and reference sources (McCoy, 2011). The use of mobile devices such as mobile phones and tabs - indicating the combination of electronic tools and the mobility of learners - in language learning is identified within Mobile Assisted Language Learning (MALL or m-learning) (Quinn, 2000; Keegan, 2005; O’Malley \& Vavoula et al., 2005). In EFL writing, in particular, there is a growing need to apply mobile learning due to its potential benefits to improve the learners' ability in EFL writing. Harmer (2011) mentions that creating interesting activities in writing is meaningful for learners' engagement. Furthermore, creating pleasant language classroom will reduce tension that affects the success of second language acquisition (Dulay, Burt, \& Krashen, 1982).

Hence, different from the previous studies on process writing approach, the current study aims at scrutinizing the combination of implementing the process writing approach with the mobile learning on the basis of video assignment, namely video-based mobile learning. Ting (2013) stated that videos created by learners are beneficial to integrate language learning to the real-life context outside the language classroom. Language learning can be built more meaningful through video projects as learners are exposed to cope with authentic learning environment (Brown \& Kegan, 1986; Che Mat et al., 2017). This is because videos can be easily stored in mobile devices and learners can repeatedly access to the video link to observe the mistakes they have done and make necessary improvements to their language use. 
Since the implementation of video-based mobile learning in enhancing the writing skill requires the creativity of learners, creativity level is put into concern as one of the variables in this research. Whalley et al. (2006) mention that mobile technology used in language instruction such as photos and video-making fosters the learners' creativity in developing novel ideas. The excitement of video production is an experience which can be one choice to EFL learners to express their creativity. Harmer (2005) mentions that video making activities can be used as a springboard of learners' creativity and as a chance to display their work and get feedback on it from classmates as well as teachers. Petersen et al. (2012) stated that learners' autonomy motivated their divergent skill in language learning in which learners with high and low-creativity are enforced to "think outside the box". Thus, ideally, with exposure on video assignment, learners with high creativity level achieve better in writing skill than the low-creativity learners.

The present research deals with mobile learning conducted through video making assignment in process writing approach. The combination of process writing approach and video-based mobile learning is believed to be able to overcome EFL learners' problems in EFL writing and increase their engagement in the writing process.

\section{REVIEW OF LITERATURE}

\section{Process Writing Approach}

Some literature suggests that the process writing approach comprises five stages, namely pre-writing or planning - drafting - revising - editing - publishing (Grenville, 2001; Murray, 2004). Previous studies on the implementation of process writing approach have been conducted (e.g., Arslan \& Kizil, 2010; Timothy Kolade, 2012; Arici \& Kaldirin, 2015; Faraj, 2015; Papilaya, 2018). The successful results showed that the process approach on essay writing was effective to develop the students' writing skill (Timothy Kolade, 2012) as well as to reduce the anxiety in writing (Arici \& Kaldirin, 2015). Additionally, the idea of integrating ICT in the implementation of process writing approach such as blog software (Arslan \& Kizil, 2010), internet (Faraj, 2015), and mobile phone (Papilaya, 2018) has successfully advanced the learners' writing performance.

\section{Mobile Learning}

MALL is stipulated as a new pedagogical platform for language learning and teaching. Mobile devices such as smart phones are able to change the conventional teaching into more attractive and flexible instruction, adapt the instruction atmosphere, and obtain information "anywhere" and at "anytime", or in and out of the classroom (Berger, 2001; Clarke \& Flaherty, 2002; Ally, 2009; Hockly, 2013). Learners can use mobile devices to select and adjust the learning materials as well as engage in collaborative projects to (Traxler, 2009; Hsieh \& Tsai, 2017). A number of studies reported the application of mobile learning (e.g., Miangah, 2012; Fattah, 2015; Nalliveettil \& Alenazi, 2016). Miangah's (2012) research showed that the use of mobile phones improved Iranian students' learning of vocabulary, listening, grammar, phonetics, and reading comprehension. Fattah (2015) found that essay writing through WhatsApp messaging enhanced the students' active participation in the EFL classroom. Nalliveettil and 
Alenazi (2016) reported the result of survey involving male undergraduate students majoring English at Aljouf University, Saudi Arabia, which showed that $67 \%$ of the students believe that mobile phones can develop their English spelling skills.

\section{Video Assignment}

A review of literature suggests that video assignment enable the learners with different learning styles to work cooperatively, think critically, and take on creative roles (McGovern, 1983; Thieman, 2008; Xiang, 2018). The task of making video can trigger learners to use language authentically and it can help learners communicate messages efficiently in a short period of time (Kierran \& Xierri, 2017). Through videos they make, learners are challenged to creatively cope with real-world issues nowadays. A number of studies in video assignment have been applied in EFL classroom (Ting, 2013; Hidayati $\&$ Nurjanah, 2017). Using Windows Movie Maker Media in video assignment, the study revealed that learners were generally positive and enthusiastic about the video making (Ting, 2013) and it can improve the learners' writing skill (Hidayati \& Nurjanah, 2017). A study conducted by Cahyono and Rahayu (2015) investigating the implementation of using video-based task to record activities in writing process analysis essay showed that video-based task improved the students' ability in essay writing skill.

\section{Creativity in Language Learning}

There has been limited studies on creativity in EFL teaching and learning (Dörnyei, 2005; Albert, 2006; Maley \& Kiss, 2018). Studies on the relationship between the creativity and language learning have been conducted (e.g., Pishgadam et al, 2011; Wati et al, 2011; Ghonsooly and Showqi, 2012; Soraya, 2016). Pishghadam et al. (2011) conducted research to examine the correlation between creativity and foreign language performance. A creativity test was done to 272 undergraduate students in north-eastern Iran and the results from Pearson product-moment correlation found a significant correlation between learners' creativity and their foreign language performance. Further, Ghonsooly and Showqi (2012) conducted a study on the relationship between mastering a foreign language and creativity. The result showed that the mastery of a foreign language in a classroom increases the creative thinking ability: fluency, elaboration, originality, and flexibility. Accordingly, research on the effect of creativity levels in writing (Wati et al., 2012; Soraya 2016) implied that learners with high creativity level had better writing achievement than those with low creativity level.

With regard to the concept of creativity, Dörnyei (2005) states that nearly all researchers claim that there is no particular definition on creativity. Creativity is the process of creating original and unique product as well as expressing new ideas. It refers to the ability to produce novel theories, solutions, concepts as well as artistic expression (Grainger, 2005; Kaufman, Plucker, \& Baer, 2008). Meanwhile, Munandar (1999) mentions that verbal creativity can be measured from the fluency, flexibility, and originality in expressing ideas in words and sentences.

Research studies in the process writing approach, mobile learning, and video project have shared the same successful results. However, there was limited literature on the idea of combining mobile learning and video in the employment of process writing 
approach. The current study also fulfilled the gaps from the previous studies in the exertion of creativity levels as a factor that might support the strength of the relationship between the strategy and the writing skill. Therefore, in the present research we investigated the effect of process writing approach combined with video-based mobile learning on the writing skill of EFL learners across creativity levels. The current study adapted the four criteria of creativity proposed by (Greenstein, 2012) namely novelty, elaboration, originality, and divergent. The research questions are formulated as follows:

1. Is there any difference in writing skill between EFL learners taught using process writing approach combined with video-based mobile learning and those taught using the conventional method?

2. Is there any difference in writing skill between EFL learners who have high and low creativity levels after being taught using process approach combined with videobased mobile learning?.

\section{METHOD}

\section{Subjects}

This study employed a quasi-experimental design due to the school system that prohibited forming natural randomization of groups. The study involved the second graders of Vocational High School 2 at Batu City, East Java, Indonesia. The characteristics of the subjects were determined for some reasons: the learners have learned English for two semesters and were prepared for the student's competence competition in which the writing skill in English was particularly needed. Two accessible intact classes with the minimum number of 30 learners within a class were chosen as the sample of the study which involved sixty-one learners of Post Harvest Study Program. The learners were divided into two groups based on the two selected classes in the study program. The first class which consisted of 31 learners were randomly assigned as the experimental group, while the second class which consisted of 30 learners were assigned as the control group.

\section{Procedures}

This study included two variables: independent and dependent variables. The independent variables had two variants: the application of process writing approach combined with video-based mobile learning as the active variable and the learners' creativity levels (high and low) as the moderating variable. The dependent variable was the learners' writing skill.

There were five sessions including the administration of pre-test and post-test. In the pre-test administered in the first meeting, the learners were asked to write a procedure text on food technology by choosing one out of four topics provided: How to make chicken floss; How to make pineapple jam; How to make soybean cake; and How to make apple juice. Those topics were selected due to the importance of post harvest learners' pre knowledge in text composition.

In the treatment, the learners learned to write procedural texts in 3 meetings each of which ran for 135 minutes. Both experimental and control groups were taught to write 
procedure texts through process writing approach. Process writing consists of 5 stages: pre-writing or planning - drafting - revising - editing - publishing (Grenville, 2001; Murray, 2004). These stages of writing were conducted at three sessions: (1) Planning was conducted by assigning the learners to work in pairs; (2) Drafting and revising were conducted by asking the learners to work individually; and (3) editing and publishing were conducted individually as well.

The schedule of treatment for the two groups is shown in Table 1.

Table 1

Schedule for the Treatment

\begin{tabular}{|c|c|c|}
\hline \multirow[b]{2}{*}{ Meeting } & \multicolumn{2}{|l|}{ Activities } \\
\hline & $\begin{array}{l}\text { The experimental group } \\
\text { (The process approach combined with } \\
\text { video-based mobile learning) }\end{array}$ & $\begin{array}{l}\text { The control group } \\
\text { (The conventional teaching) }\end{array}$ \\
\hline 1 & Pre-test: & Pre-test: \\
\hline 2 & $\begin{array}{l}\text { The planning stage: } \\
\text { Brainstorming ideas, analyzing genre } \\
\text { of procedure text, discussing } \\
\text { vocabulary item, and selecting topics } \\
\text { for writing. The topics were the } \\
\text { procedures on food technology } \\
\text { practicum in post harvest program. } \\
\text { Homework, the learners were asked to } \\
\text { collect photos concerning the topics. }\end{array}$ & $\begin{array}{l}\text { The planning stage: } \\
\text { Brainstorming ideas, analyzing genre of } \\
\text { procedure text, discussing vocabulary } \\
\text { item, and selecting topics for writing. The } \\
\text { topics were the procedures on food } \\
\text { technology practicum in post harvest } \\
\text { program. } \\
\text { Homework, the learners were asked to } \\
\text { collect ideas concerning the topics. }\end{array}$ \\
\hline 3 & $\begin{array}{l}\text { The drafting and revising stages: } \\
\text { Drafting using mind mapping, } \\
\text { developing into composition, and } \\
\text { checking the organization and content } \\
\text { of the text. } \\
\text { Involving the learners in video- } \\
\text { making assignment using video editor } \\
\text { application in mobile phone. }\end{array}$ & $\begin{array}{l}\text { The drafting and revising stages: } \\
\text { Drafting using mind mapping, developing } \\
\text { into composition, and checking the } \\
\text { organization and content of the text. } \\
\text { Involving the learners in writing } \\
\text { assignment using coloured paper. }\end{array}$ \\
\hline 4 & $\begin{array}{l}\text { The Editing and publishing stages: } \\
\text { Improving the vocabulary, grammar, } \\
\text { and mechanic aspect (such as, } \\
\text { punctuation and spelling). } \\
\text { Publishing the video by sending it to } \\
\text { the teacher's WhatsApp account. The } \\
\text { learners were also asked to complete } \\
\text { the questionnaire of creativity level. }\end{array}$ & $\begin{array}{l}\text { The Editing and publishing stages: } \\
\text { Improving the vocabulary, grammar, and } \\
\text { mechanic aspect (such as, punctuation } \\
\text { and spelling). } \\
\text { Publishing the writing using display } \\
\text { board. }\end{array}$ \\
\hline 5 & Post-test: & Post-test: \\
\hline
\end{tabular}

The experimental and the control groups received different treatment. The learners in the experimental group were exposed to group individual assignment on video-making project assisted by mobile phones (android). In the video-making assignment, each of the learners was asked to make a procedure text and record it in a video. The video can be one of three types: (1) it may contain slides of images with texts, or (2) movie with texts, or (3) combination of the two types. All of the learners were able to complete the 
task given in the project. Some of the learners' videos were of the first type, and some others' videos were of the second and third types. They also provided their video with background music. Some titles of the learners' videos are: Making Salted Eggs, How to Make Chicken Sausage, and How to Make Dragon Fruit Noodle.

In the conventional method applied to the control group, the process writing approach has been employed for the last three years whereas the treatment of the experimental group emphasized the combination of process writing approach and video-based mobile learning which was not experienced by the learners in the control group. Additionally, the learners in the control group were not allowed to use mobile phones in the classroom. They were given worksheets to complete all the tasks without any activities engaging with video and mobile phone.

Following the treatment, the post-test was administered in the fifth meeting. In the posttest, the learners were asked to write a topic different from topics assigned in the pre-test and writing assignments to avoid the threat of testing effect. They were asked to select one of these four topics: How to make strawberry juice; How to make chicken nugget; How to make beet fruit noodle; and How to make bark sweets.

\section{Instruments}

Three research instruments were used in this study namely writing tests, scoring rubric and questionnaire. The writing tests were applied to collect data on learners' writing scores. The scoring rubric was based on the need in scoring procedure text, adapted from Reid (1993) and Brown (2006). It consisted of five components: content (30\%), organization $(20 \%)$, vocabulary (20\%), language use $(20 \%)$, and mechanics $(10 \%)$. The instruments for writing tests have been validated by experts in foreign language writing to ensure that there was no problem with construct and content validity problem on the writing prompts. The try-out of the writing test was carried out before administering the pre-test, and the result of Pearson Product Moment Correlation on each component (content, organization, vocabulary, language use, mechanics) explained that all items were valid.

Referring to the reliability of the writing test, two different raters scored the learners' compositions and the inter-rater reliability of the scores was ensured using the Intraclass Coefficient Correlation (ICC) and Cronbach's Alpha. The analysis on reliability perceived that the average of alpha coefficient was 0.73 which was interpreted as having high reliability.

The last instrument used in this study was the creativity questionnaire which was adapted from Greenstein (2012) covering four aspects: novelty, elaboration, originality and divergent. The novelty deals with the use of new and unique ideas different from what have been known. Elaboration is about adding details to something to make the ideas better. Originality is the nature of the idea which comes up from the writer. Divergent refers to the idea of combining, modifying, and rearranging to improve the quality of the products. 
The questionnaire involved 11 questions using Guttman Scale (Miller \& Salkind, 2002) in which two intervals namely "yes" or "no" are chosen to gain a firm answer from the provided questions. Further, the questionnaire was then tried out and analysed using Pearson Product Moment Correlation and Cronbach Apha Coefficient. The result of the analysis confirmed all items were valid with the alpha coefficient of 0.78 which was categorized as high reliability questionnaire. The questionnaire was carried out on line via Google form and presented as shown in Figure 1.

\section{Creativity Questionnaire}

Direction: For each statement, please give your response by ticking a box representing your choice.

Part 1: Novelty

1. I am intrigued by the unique things and interesting ideas.

$\begin{array}{ll}\text { a. } & \text { Yes b. No } \\ \text { I often wonder about ideas and need }\end{array}$ help to explore unique ways of thinking and doing.
a.
Yes
b. No

Part 2: Elaboration

3.

the idea to make it better.

a.

4. ways to add details to make the ideas better. a.

Part 3: Originality

5.

on most topics.

6. a. original ideas. a.

7.

a.

Part 4: Divergent

8. and adapt them for better result. a.

9. to improve the outcomes. a.

10. the box". I like things as they are.

11. a.

are relatively simple. a.

Figure 1

Creativity Questionnaire
It is easy and fun to add details to

$$
\text { Yes b. No }
$$

Sometimes I just can't think of Yes

b. No

I can come up with many new ideas Yes b. No

I can create new products from my

$$
\text { Yes b. No }
$$

I need help thinking of new ideas.

Yes b. No

It is easy for me to combine ideas

Yes b. No

I like to modify and rearrange ideas

Yes b. No

It's hard for me to "think outside

Yes b. No

I can combine my ideas, but they

Yes b. No 


\section{Data Analysis}

Firstly, the pre-test data was analysed to ensure the group equivalency and support the information about the learners' characteristics in both groups. Then, the fulfilment of the statistical assumption was accomplished using homogeneity and normality tests from the learners' writing scores of pos-test. The result from the Levene's and Saphiro Wilk tests was established that the two groups were homogenous and the data were in normal distribution. Accordingly, the analysis on the comparison of the post-test scores of the experimental and control groups as well as the comparison of the post-test scores of the sub-groups - high-creativity and low-creativity learners - were conducted by using parametric statistic analysis of $t$-test.

\section{FINDINGS}

In order to answer the research questions (RQs), the pre-test scores of the learners from the experimental and control groups were initially compared. The descriptive statistics of the writing pre-test from Table 2 depicted that the mean score of the experimental group was 55.97 with the standard deviation 5.62. Meanwhile, the mean score and the standard deviation of the control group was 55.60 and 5.21, respectively.

Table 2

Descriptive Statistics of the Pre-test Scores of the Learners from the Experimental and Control Groups

\begin{tabular}{lllll}
\hline Score & Group & $\mathrm{N}$ & Mean & Std. Deviation \\
\hline \multirow{2}{*}{ Pre-test } & Experimental & 31 & 55.97 & 5.62 \\
& Control & 30 & 55.60 & 5.21 \\
\hline
\end{tabular}

The result of the comparison of the pre-test scores using independent sample t-test implied that there was no significant difference in the pre-test scores between the experimental group $(\mathrm{p}$-value $=0.792)$ before the treatment, meaning that the writing skill of both groups were equal (see Table 3 ).

Table 3

Comparison of the Pre-test Scores Using Independent Sample T-test

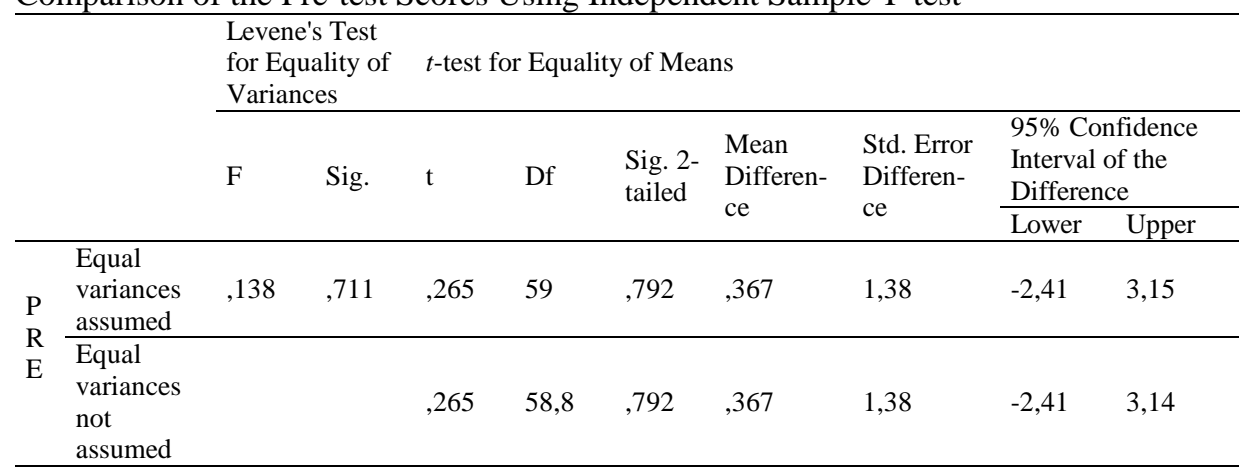




\section{Comparison of the Post-test Scores of the Learners from the Experimental and Control Groups}

The descriptive statistics of post-test scores of the experimental and control groups showed that the mean score of the experimental group was 78.11 with the standard deviation 4.64. Meanwhile, the mean score and the standard deviation of the control group was 70.05 and 3.68 , respectively (see Table 4). Comparing the descriptive statistics on the mean scores of the pre-test, it asserted that there was an improvement on the learners writing skill after the treatment.

Table 4

Descriptive Statistics of the Post-test Scores of the Learners from the Experimental and Control Groups

\begin{tabular}{lllll}
\hline Score & Group & N & Mean & Std. Deviation \\
\hline \multirow{2}{*}{ Post-test } & Experimental & 31 & 78.11 & 4.64 \\
& Control & 30 & 70.05 & 3.68 \\
\hline
\end{tabular}

The independent-sample t-test was then applied to examine the effect of process approach combined with video-based mobile learning on the learners' writing skill (RQ 1) and the result was displayed in Table 5.

Table 5

Comparison of the Post-test Scores using Independent Sample T-test

\begin{tabular}{|c|c|c|c|c|c|c|c|c|c|c|}
\hline & & $\begin{array}{l}\text { Lever } \\
\text { for Ec } \\
\text { Varia }\end{array}$ & $\begin{array}{l}\text { S Test } \\
\text { ality of } \\
\text { es }\end{array}$ & $t$-test & Equal & of Mear & & & & \\
\hline & & $\mathrm{F}$ & Sig. & $\mathrm{t}$ & Df & $\begin{array}{l}\text { Sig. 2- } \\
\text { tailed }\end{array}$ & $\begin{array}{l}\text { Mean } \\
\text { Differen- }\end{array}$ & $\begin{array}{l}\text { Std. Error } \\
\text { Differen- }\end{array}$ & $\begin{array}{l}95 \% \mathrm{Co} \\
\text { Interval } \\
\text { Differer }\end{array}$ & $\begin{array}{l}\text { idence } \\
\text { the }\end{array}$ \\
\hline & & & & & & & & & Lower & Upper \\
\hline $\begin{array}{l}\mathrm{P} \\
\mathrm{O}\end{array}$ & $\begin{array}{l}\text { Equal } \\
\text { variances } \\
\text { assumed }\end{array}$ & 967 & ,329 & 7,50 & 59 & ,000 & 8,06 & 1,07 & 5,91 & 10,21 \\
\hline $\begin{array}{l}S \\
T\end{array}$ & $\begin{array}{l}\text { Equal } \\
\text { variances } \\
\text { not } \\
\text { assumed }\end{array}$ & & & 7,53 & 56,8 & ,000 & 8,06 & 1,07 & 5,92 & 10,21 \\
\hline
\end{tabular}

The statistical data in Table $5(\mathrm{p}$-value $=0.000)$ indicated that there was a significant difference on the post-test scores between the experimental and control groups of learners. The mean of the learners from the experimental group (78.11) was higher than the mean of the learners from the control group (70.05). Based on the result of the comparison of post-test scores, it can be inferred that the learners taught by using videobased mobile learning achieved better writing skill than those taught by using the conventional method. 


\section{Comparison of the Writing Skill between High-creativity and Low-creativity Learners Taught by Using Video-based Mobile Learning}

Since Research Question 2 is intended to determine whether the creativity level of the learners in the experimental group contributed to the effect of treatment or not, the independent-sample $t$-test was employed and the result is shown in Table 6.

Table 6

Comparison of the Post-test Scores between High-Creativity and Low-Creativity Learners in the Experimental Group using Independent Sample T-test

\begin{tabular}{|c|c|c|c|c|c|c|c|c|c|c|}
\hline & & \multicolumn{2}{|c|}{$\begin{array}{l}\text { Levene's Test } \\
\text { for Equality of } \\
\text { Variances } \\
\end{array}$} & \multicolumn{7}{|c|}{$t$-test for Equality of Means } \\
\hline & & \multirow[t]{2}{*}{$\mathrm{F}$} & \multirow[t]{2}{*}{ Sig. } & \multirow[t]{2}{*}{$\mathrm{t}$} & \multirow[t]{2}{*}{ df } & \multirow[t]{2}{*}{$\begin{array}{l}\text { Sig. 2- } \\
\text { tailed }\end{array}$} & \multirow[t]{2}{*}{$\begin{array}{l}\text { Mean } \\
\text { Differen- } \\
\text { ce }\end{array}$} & \multirow{2}{*}{$\begin{array}{l}\text { Std. Error } \\
\text { Differen- } \\
\text { ce }\end{array}$} & \multicolumn{2}{|c|}{$\begin{array}{l}95 \% \text { Confidence } \\
\text { Interval of the } \\
\text { Difference }\end{array}$} \\
\hline & & & & & & & & & Lower & Upper \\
\hline $\begin{array}{l}P \\
O\end{array}$ & $\begin{array}{l}\text { Equal } \\
\text { variances } \\
\text { assumed } \\
\end{array}$ & ,409 &, 527 & 1,26 & 29 &, 217 & 2,09 & 1,65 & $-1,29$ & 5,48 \\
\hline $\begin{array}{l}\mathrm{S} \\
\mathrm{T}\end{array}$ & $\begin{array}{l}\text { Equal } \\
\text { variances } \\
\text { not } \\
\text { assumed }\end{array}$ & & & 1,27 & 28,4 &, 214 & 2,09 & 1,64 & $-1,28$ & 5,47 \\
\hline
\end{tabular}

The comparison as shown in Table 6 revealed that there was no significant difference in the writing skill of the learners with high and low-creativity levels (p-value=0.217). In conclusion, the categorization of creativity level (high and low) had no effect on the writing skill of the learners taught by process writing approach combined with videobased mobile learning.

\section{DISCUSSION}

In reference to the research findings on the statistical analysis using t-test, it was found the learners taught using process writing approach combined with video-based mobile learning had better writing skill than of those taught using conventional method. The results of data analysis have been presented by referring to the two research questions.

The effectiveness of applying process writing approach combined with video-based mobile learning on teaching procedure text writing was due to some aspects. First, the process writing approach gave opportunity of the learners' engagement in writing composition confidently. With regard to the first research question, the result of this study indicated that process writing approach combined with video-based mobile learning was effective to develop foreign language learning. It was proved by the result of the post-test showing that there was a significant difference in the writing skill of the learners. This result supported the findings from previous studies on the implementation of process approach in writing that this strategy was effective to enhance the learners writing skill (see Arslan \& Kizil, 2010; Timothy Kolade, 2012; Arici \& Kaldirin, 2015; Faraj, 2015; Papilaya, 2018). Meanwhile, the differences were also found in the ICT media combined. Arslan and Kizil (2010) integrated the process writing approach with 
blog software, Faraj (2015) with internet, and Papilaya (2018) utilized mobile phone. In contrast, the present study attempted to blend the process writing approach with videomaking assignment using mobile phone. Comparable with those findings, in terms of implementing process writing approach, the current study performed the same successful result.

Second, mobile phone, as the ICT media for searching information helped the learners to generate ideas on the stages of writing process. This was in agreement with the statement of Cahyono and Mutiaraningrum (2016) that integrating ICT and internet in language classroom was effective to enhance the learners writing performance. Additionally, this become another evidence that supported the previous studies on the benefit of mobile phone to assist the language learning (see Miangah, 2012; Fattah, 2015; Nalliveettil \& Alenazi, 2016)

Third, the activity of video-making assignment boosted the learners' interest in mastering foreign language, particularly in writing skill. Creating individually video assignments was a sort of amusing activity since it reflected today's lifestyle of learners. Within the scope of Second Language Acquisition (SLA) theories, Dulay, Burt \& Krashen (1982) mentions that the success of language acquisition is affected by the convenient learning atmosphere and the low strain of learners. In addition, this finding was in line with the result from previous studies on the exposure of video-making assignment as a source of technology information in enhancing language learning (see Ting, 2013; Cahyono \& Rahayu, 2015; Hidayati \& Nurjanah, 2017). Regardless the different media used in the previous studies, the findings indicated that video assignment could develop the learners' writing skill. The idea of combining media in writing activities was proved to be a good choice in promoting the learners' language performance. This concept strengthened the theory that video assignment encourage learners' participation (McGovern, 1983; Thieman, 2008; Xiang, 2018) as well as help them delivering information precisely (Kierran and Xerri's, 2017).

The second research question deals with the comparison of the writing skill between high and low creativity learners in the experimental group. Previously, it has been discussed that video-based mobile learning has shared significant result in enhancing learners' writing skill. On the contrary, the result of the comparison between the high and low creativity learners in the experimental group revealed that there was no significant difference on the post-test scores ( $p$-value $=0.217)$. This finding in this study differed from the finding of a study conducted by Wati et al. (2012) and Soraya (2016). Contrasting with the present findings, the result from the previous studies (Wati et al., 2012; Soraya 2016) revealed that learners who had high creativity had better writing achievement than those who had low creativity. Meanwhile, the current study indicated that the writing skill of high and low creativity learners after getting process approach combined with video-based mobile learning treatment was equal.

Accordingly, the finding was supported by the rationale that video assignment can be stored and played repeatedly by the learners. Thus, the learners with high and lowcreativity level had the same opportunity to revise the writing. 


\section{CONCLUSION}

The present study examined the effect of process writing approach combined with video-based mobile learning across creativity levels. In a nutshell, video-based mobile learning can be chosen as an alternative of teaching foreign language writing. The effectiveness of video-based mobile learning was supported by some factors: the learners' engagement in process writing approach, the assistance of mobile learning as sources of information and learning material, video-making assignment as a chance to display learners' writing, and the relaxed ambience during the treatment. Apart from the successful result in the implementation of video-based mobile learning on the writing skill of Indonesian EFL learners, it is discovered that the writing skill between high and low creativity learners in experimental group were not significantly different. Interestingly, it can be reported that the low creativity level can develop their writing skill as better as the high creativity learners. This suggested that whenever EFL teachers would like to apply video-based mobile learning, they should not worry about the creativity level of their learners.

\section{REFERENCES}

Ally, M. (Ed.). (2009). Mobile learning: transforming the delivery of education and training. Edmonton: AU Press.

Arici, A. F., \& Kaldirim, A. (2015). The effect of the process-based writing approach on writing success and anxiety of pre-service teachers. The Anthropologist, 22(2), 318327. https://doi.org/10.1080/09720073.2015.11891883

Arslan, R. Ş., \& Şahin-Kızıl, A. (2010). How can the use of blog software facilitate the writing process of English language learners? Computer Assisted Language Learning, 23(3), 183-197. https://doi.org/10.1080/09588221.2010.486575

Berger, C. (2001). Wireless: Changing teaching and learning 'everywhere, everytime'. Educause Review, 36(1), 58-59.

Brown, H. D. (2006). Language assessment: Principles and classroom practices. New York: Longman.

Cahyono, B.Y. (Ed). (2009). Techniques in teaching EFL writing. Malang: State University of Malang Press.

Cahyono, B. Y., \& Mutiaraningrum, I. (2015). Indonesian EFL teachers' familiarity with and opinion on the internet-based teaching of writing. English Language Teaching, 9(1), 199. https://doi.org/10.5539/elt.v9n1p199

Cahyono, B. Y., \& Rahayu, T. (2015). Using video-based tasks for teaching writing process analysis essay. In B. Y. Cahyono (Ed.), Inspirations and innovations for English classroom (pp. 345-362). Malang: State University of Malang.

Cahyono, B. Y., \& Widiati, U. (2006). The teaching of EFL writing in Indonesian context: the state of art. Jurnal Ilmu Pendidikan, 13(3), 139-150. 
Che Mat, A., Awang, A., Nokman, A. Z., Musilehat, N., \& Bakar, A. F. A. (2017). An authentic learning environment based on video project among Arabic learners. International Journal of Applied Linguistics and English Literature, 6(4), 143-148. https://doi.org/10.7575/aiac.ijalel.v.6n.4p.143

Clarke, I., \& Flaherty, T. B. (2002). mLearning: Using wireless technology to enhance marketing education. Marketing Education Review, 12(3), 67-78. https://doi.org/10.1080/10528008.2002.11488801

Dörnyei, Z. (2005). The psychology of the language learner: individual differences in second language acquisition. Mahwah, N.J: L. Erlbaum.

Dulay, H. C., Burt, M. K., \& Krashen, S. D. (1982). Language two. New York: Oxford University Press.

Faraj, A. K. A. (2015). Scaffolding EFL students' writing through the writing process approach. Journal of Education and Practice, 6, 131-141.

Fareed, M., Ashraf, A., \& Bilal, M. (2016). ESL Learners' Writing Skills: Problems, Factors and Suggestions. Journal of Education \& Social Sciences, 4(2), 83-94. https://doi.org/10.20547/jess0421604201

Fattah, S. F. E. S. A. (2015). The effectiveness of using WhatsApp messenger as one of mobile learning techniques to develop students' writing skills. Journal of Education and Practice, 6(32), 115-127.

Ghonsooly, B., \& Showqi, S. (2012). The Effects of foreign language learning on creativity. English Language Teaching, 5(4), 161-167. https://doi.org/10.5539/elt.v5n4p161

Grainger, T. (2005). Teachers as writers: learning together. English in Education, 39(1), 75-87. https://doi.org/10.1111/j.1754-8845.2005.tb00611.x

Greenstein, L. (2012). Assessing $21^{\text {st }}$ century skills: A guide to evaluating mastery and authentic learning. Thousand Oaks, CA: Corwin Press.

Grenville, K. (2001). Writing from start to finish: A six-step guide. Crows Nest, N.S.W: Allen \& Unwin.

Harmer, J. (2005). The practice of English language teaching (3. ed.). Harlow: Longman.

Harmer, J. (2011). How to teach writing. Harlow: Longman, Pearson Education.

Hidayati, R. P. P., \& Nurjanah, S. (2017). Implementation of project-based learning model with windows movie maker media in improvement of short story writing. Journal of Education, Teaching and Learning 2(1), 164-167.

Hockly, N. (2013). Mobile learning. ELT Journal, 67(1), 80-84. https://doi.org/10.1093/elt/ccs064 
Hsieh, W.-M., \& Tsai, C.-C. (2017). Taiwanese high school teachers' conceptions of mobile learning. Computers \& Education, 115 (Supplement C), 82-95. https://doi.org/10.1016/j.compedu.2017.07.013

Hyland, K. (2003). Second language writing. Cambridge: Cambridge University Press.

Kaufman, J. C., Plucker, J. A., \& Baer, J. (2008). Essentials of creativity assessment. Hoboken, N.J: Wiley.

Keegan, D. (2005). The incorporation of mobile learning into mainstream education and training, World Conference on Mobile Learning, Cape Town. Retrieved September 27, 2017, from http://www.mlearn.org.za/CD/papers/keegan1.pdf

Kieran, D., \& Xerri, D. (Ed.). (2017). The image in English language teaching. Malta: ELT Council.

Klimova, B. F. (2012). The importance of writing. Paripex - Indian Journal Of Research, 2(1), 9-11. https://doi.org/10.15373/22501991/JAN2013/4

McGovern, J. (1983). Video applications in English language teaching ( $\left.1^{\text {st }} \mathrm{ed}\right) . \mathrm{New}$ York: Pergamon Press in association with the British Council.

Miangah, T. M. (2012). Mobile-assisted language learning. International Journal of Distributed and Parallel Systems, 3(1), 309-319. https://doi.org/10.5121/ijdps.2012.3126

Miller, D.C., Salkind, N.J. (2002). Handbook of research design and social measurement $\left(6^{\text {th }}\right.$ ed.). California: Sage Publications.

Munandar, U. (1999). Pengembangan kreativitas anak berbakat. Jakarta: Departemen Pendidikan \& Kebudayaan: Reneka Cipta.

Murray, D. M. (2004). A writer teaches writing (2nd ed). Boston: Thomson/Heinle.

Nalliveettil, G. M., \& Alenazi, T. H. K. (2016). The impact of mobile phones on English language learning: Perceptions of EFL undergraduates. Journal of Language Teaching and Research, 7(2), 264-272. https://doi.org/10.17507/jltr.0702.04

O’Malley, C., Vavoula, G., Glew, J., Taylor, J., Sharlpes, M., Lefrere, P., Lonsdale, P. Naismith, \& Waycott, J. (2005). Guidelines for learning/teaching/tutoring in a mobile environment, (Online), Retrieved October 4, 2017, from https://hal.archivesouvertes.fr/hal-00696244/document

Papilaya, R. (2018). Effect of process approach combined with internet resources through mobile phone on EFL students' ability in writing. (Unpublished master's thesis). Universitas Negeri Malang, Malang.

Petersen, S. A., Procter-Legg, E., \& Cacchione, A. (2013). Creativity and mobile language learning using LingoBee: International Journal of Mobile and Blended Learning, 5(3), 34-51. https://doi.org/10.4018/jmbl.2013070103 
Pishghadam, R., Khodaday, E., \& Zabihi, R. (2011). Learner creativity on foreign language achievement. European Journal of Educational Study, (3)3, 465-472.

Quinn, C. (2000). mLearning: Mobile, wireless, in-your-pocket learning, Linezine. Fall 2000. Retrieved October 4, 2017, from http://www.linezine.com/2.1/features/cqmmwiyp.htm

Reid, J. M. (1993). Teaching ESL writing. Englewood Cliffs, NJ: Regents/Prentice Hall.

Richards, J. C., \& Renandya, W. A. (Eds.). (2013). Methodology in language teaching: an anthology of current practice (1st publ., 17. print). Cambridge: Cambridge Univ. Press.

Soraya, K. (2016). The effectiveness of collaborative writing strategy (CWS) in writing lesson regarded to the students' creativity. Lingua Cultura, 10(2), 63-67. https://doi.org/10.21512/lc.v10i2.898

Thieman, G. Y. (2008). Using technology as a tool for learning and developing $21^{\text {st }}$ century citizenship skills: An examination of the NETS and technology use by preservice teachers with their K-12 students. Contemporary Issues in Technology and Teacher Education, 8(4), 342-366.

Timothy Kolade, A. (2012). The influence of process approach on English as second language students' performances in essay writing. English Language Teaching, 5(3), 16-29. https://doi.org/10.5539/elt.v5n3p16

Ting, N. C. (2013). Classroom video project: An investigation on students perception. Procedia - Social and Behavioral Sciences, 90, 441-448. https://doi.org/10.1016/j.sbspro.2013.07.113

Traxler, J. (2009). Learning in a mobile age: International Journal of Mobile and Blended Learning, 1(1), 1-12. https://doi.org/10.4018/jmbl.2009010101

Wang, Z. (2014). An analysis on the use of video materials in college English teaching in China. International Journal of English Language Teaching, 2(1), 23-28. https://doi.org/10.5430/ijelt.v2n1p23

Wati, N. S., Nurkamto, J., \& Rochsantiningsih, D. (2012). The effectiveness of collaborative writing method to teach writing skill viewed from student creativity. Journal of English Teaching 1(1), 37-53.

Whalley, J., Welch, T., \& Williamson, L. (2006). e-Learning in FE. Gosport: Continuum International Publishing Group.

Xiang, C. H. (Ed.). (2018). Cases on audio-visual media in language education. Hershey, PA: Information Science Reference (an imprint of IGI Global). 